\title{
ATPase Activity and Calcium Uptake of Microsomes Isolated from Stomach Smooth Muscle after Exposure to Phospholipase C
}

\author{
Yasushi SaKaI, Santa IchiKawa, Masahide Yoshida \\ Michiko OoụchI and Masamitsu MiYagawA \\ Department of Physiology, Showa University School of Medicine, \\ 1-5-3 Hatanodai, Shinagawa-ku, Tokyo 142, Japan
}

\begin{abstract}
Summary
Sakai,Y., Ichikawa, S., Yoshida, M., Oouchi, M. and Miyagawa, M. ATPase Activity and Calcium Uptake of Microsomes Isolated from Stomach Smooth Muscle after Exposure to Phospholipase C. Japanese J. Smooth Muscle Res., 1982, 18, (5), 339-345. ATPase activity and $\mathrm{Ca}^{2+}$ uptake were examined in microsomal membrane fractions isolated from guinea pig stomach smooth muscle which had been exposed to phospholipase C (PLC). Basal $\mathrm{Mg}^{2+}$-ATPase, $\mathrm{Na}^{+}, \mathrm{K}^{+}$-ATPase and $\mathrm{Ca}^{2+}, \mathrm{Mg}^{2+}-\mathrm{ATP}$ activities were inhibited in a time dependent manner by PLC treatment. There was positive correlatioon between each of these ATPase activities and total phospholipid content of the microsomal fraction. Phosphotidylcholine restored $\mathrm{Ca}^{2+}, \mathrm{Mg}^{2+}$-ATPase activity of the microsomal fraction isolated from the tissue which had been treated with PLC for $30 \mathrm{~min}$ but not after $60 \mathrm{~min}$. $\mathrm{Ca}^{2+}$ uptake in the presence of ATP by microsomal fraction from tissue treated with PLC for $60 \mathrm{~min}$ was significantly decreased. The results provide a cellular basis for the inhibitory effect of PLC on contractility of stomach smooth muscle.
\end{abstract}

\section{Introduction}

The removal of $\mathrm{Ca}^{2+}$ from cytoplasm, a process that initiates relaxation of smooth muscle, is thought to be achieved by an energy dependent $\mathrm{Ca}^{2+}$ transport systems (Carsten \& Miller, 1977 ; Daniel et al., 1979). Such $\mathrm{Ca}^{2+}$ transport systems have been reported to be associated with isolated crude microsomal fractions (Carsten \& Miller, 1977 ; Wuytack et al., 1978) or highly purified plasma membrane fractions (Grover et al., 1980 ; Kwan et al., 1981 ; Sakai et al., 1981). It is known that phospholipase C (PLC) inhibits action potential, simultaneously depolarizing resting membrane potential; and affects the ionic permeability of neuron and muscle cell membrane (Tobias, 1958; Albuquerque \& Thesleff, 1967; Sakai, 1980). The treatment of skeletal microsomes with PLC has been shown to decrease ATPase activity, $\mathrm{Ca}^{2+}$

Accepted for publication, September 16, 1982.

坂井 泰, 市河三太, 吉田正英, 大内久ち子, 宮川政光

昭和大学医学部第二生理学教室 東京都品川区旗/台 1-5-8 
transport (Martonosi, et al., 1968) and guanylate cyclase activity (Sulakha, et al., 1976). The present work was undertaken to investigate ATPase activity and $\mathrm{Ca}^{2+}$ uptake in microsomal fractions isolated from guinea pig stomach smooth muscle treated with PLC. Results are discussed in relation to the effects of PLC on smooth muscle contractility.

\section{Methods and Materials}

Membrane Isolation: Guinea pigs weighing 250-350 g were stunned and bled. The pyloric region of the stomach was immediately removed and placed in ice-cold Krebs solution. Mucosa and connective tissues were carefully sparated from the stomach muscle layer. Approximately $1 \mathrm{~g}$ of trimmed muscle from 4-5 guinea pigs was incubated in Krebs solution which was continuously aerated with $95 \% \mathrm{CO}_{2}$ and $\mathrm{O}_{2}$ at $37 \pm 0.5^{\circ} \mathrm{C}, \mathrm{pH} 7.4$. Phospholipase C $(50 \mu \mathrm{g} / \mathrm{ml})$ was added to the incubation medium $60 \mathrm{~min}$ or $30 \mathrm{~min}$ before the end of the incubation period. Control samples were similarly incubated in Krebs solution in the absence of added PLC. The tissues were subsequently washed with ice-cold Krebs solution, blotted with filter paper and washed twice with buffer containing $250 \mathrm{mM}$ sucrose, $0.15 \mathrm{mM}$ EGTA and $40 \mathrm{mM}$ histidine buffered at $\mathrm{pH}$ 7.0. The tissues were minced with a pair of scissors in $15 \mathrm{ml}$ of the above buffer and homogenized for $15 \mathrm{sec}$ at 15,000 rpm with a motor driven homogenizer (B. Braun Model ET-20). The tissue homogenate was centrifuged at $1,000 \mathrm{~g}$ for $10 \mathrm{~min}$ to remove cell debris and connective tissues. The supernatant was centrifuged at $10,000 \mathrm{~g}$ for 10 min and filtered through layers of gauze to remove mitochondria. The microsomal fraction was obtained as sediment after subsequent centrifugation at 105,000 g for $40 \mathrm{~min}$. The pellet was washed and resuspended in $40 \mathrm{mM}$ histidine buffer without EGTA.

ATPase Assays: $\mathrm{Mg}^{2+}-\mathrm{ATPase}$ activity was measured as the release of inorganic phosphate in medium containing $100 \mathrm{mM} \mathrm{KCl}, 5 \mathrm{mM} \mathrm{MgCl}_{2}, 0.15 \mathrm{mM}$ EGTA, $5 \mathrm{mM} \mathrm{Na} \mathrm{ATP}_{2}$ and $40 \mathrm{mM}$ imidazole at $\mathrm{pH} 7.0,37^{\circ} \mathrm{C} . \mathrm{Ca}^{2+}, \mathrm{Mg}^{2+}$-ATPase activity was measured similarly in the same medium in the presence of various amounts of $\mathrm{CaCl}_{2} . \mathrm{Na}^{+}, \mathrm{K}^{+}$-ATPase activity was measured in $100 \mathrm{mM} \mathrm{NaCl}, 20 \mathrm{mM} \mathrm{KCl}, 5 \mathrm{mM} \mathrm{Mg}$-ATP, $0.15 \mathrm{mM}$ EGTA and $10 \mathrm{mM}$ Tris buffer at pH 7.5. All ATPase reactions were started by the addition of $0.2 \mathrm{ml}$ ( $80-100 \mu \mathrm{g}$ protein) of the fraction to the reaction medium ( $2 \mathrm{ml}$ final volume). Reaction was stopped after $10 \mathrm{~min}$ incubation at $37^{\circ} \mathrm{C}$ by addition of $2 \mathrm{ml}$ cold $10 \%$ TCA.

$\mathrm{Ca}^{2+}$ uptake: $\mathrm{Ca}^{2+}$ uptake was measured by Millipore filtration technique (Janis et al., 1977). The reaction medium was similar to that used for $\mathrm{Ca}^{2+}, \mathrm{Mg}^{2+}$-ATPase assay except for the addition of $0.5 \mu \mathrm{Ci}^{45} \mathrm{CaCl}_{2}$. Reactions were started by the addition of microsomal fraction to the medium and stopped by filtering through Millipore filters $(0.45 \mu \mathrm{m}$ pore size). The filters were then washed with $10 \mathrm{ml}$ of a solution containing $250 \mathrm{mM}$ sucrose and $40 \mathrm{mM}$ imidazole. ${ }^{45}$ $\mathrm{Ca}$ accumulated on the filters without the membrane fraction has been accounted for in calculation. Filiters were dissolved in $10 \mathrm{ml}$ of Bray's solution (Bray, 1960).

Other Assays: The phospholipid content of each microsomal fraction was determined by the method of Chen et al. (1965). Inorganic phosphate was measured by the method of Fiske and Subbarow (1925). Protein was determined by the method of Lowry et al. (1951).

Reagents : Phospholipase C, Phosphatidylcholine, Phosphatidylethanolamine, $\mathrm{Na}_{2} \mathrm{ATP}$ and $\mathrm{Mg}$-ATP were puchased from Sigma. ${ }^{45} \mathrm{CaCl}_{2}$ was obtained as solution in $0.5 \mathrm{M} \mathrm{HCl}$ from 
International Chemical Nuclear Co.

\section{Results}

Effect of PLC on ATPase activity in microsomal fraction.

Table 1 shows that both $\mathrm{Mg}^{2+}-\mathrm{ATP}$ ase and $\mathrm{Na}^{+}, \mathrm{K}^{+}-\mathrm{ATPase}$ activities of the microsomal membrane fraction were significantly inhibited by PLC treatment. $\mathrm{Mg}^{2+}$-ATPase activity was about four times that of the $\mathrm{Na}^{+}, \mathrm{K}^{+}$-ATPase. $\mathrm{Mg}^{2+}$-ATPase was inhibited to about $45 \%$ of the control value after 60 min PLC treatment $(\mathrm{P}>0.001) . \mathrm{Na}^{+}, \mathrm{K}^{+}-\mathrm{ATP}$ ase was inhibited to $60 \%$ of the control value $(\mathrm{P}<0.01)$.

Relationship between ATPase activities and phospholipid content in microsome fractions.

Phospholipid content changed after PLC treatment. ATPase activity and total phospholipid content were linearly related up to 60 min treatment for both $\mathrm{Mg}^{2+}$-ATPase activity and $\mathrm{Na}^{+}, \mathrm{K}^{+}-\mathrm{ATPase}$ activity as shown in Fig. 1. This could indicate that ATPase activity, in both cases, is dependent on available phospholipid, either directly or as a secondary effect of another process or factor.

$\mathrm{Ca}^{2+}$ modification of $\mathrm{Mg}^{2+}-$ ATPase activity in microsomal fractions.

Figure 2 shows changes in $\mathrm{Mg}^{2+}-\mathrm{ATPase}$ activity in the presence of $\mathrm{Ca}^{2+}$. $\mathrm{Ca}^{2+}$ enhanced $\mathrm{Mg}^{2+}$-ATPase activity in control samples and samples treated with PLC for $30 \mathrm{~min}$, but not in smaples treated with PLC for $60 \mathrm{~min}$. The differences observed here could be due to limitation of the available membrane reaction sites, or to limited availability of energy, or both.

Effects of PLC on $\mathrm{Ca}^{2+}$ uptake.

As shown in Table 2, $\mathrm{Ca}^{2+}$ uptake in the presence and absence of ATP by microsomal

Table 1. ATPase activity in microsomal fractions isolated from guinea pig stomach smooth muscle treated with phospholipase C (PLC). Data are expressed as Mean \pm S.E. The number of separate experiments are shown in the parentheses. Assay conditions are described in detail in the text.

\begin{tabular}{l|l|l}
\multicolumn{3}{c}{ ATPase Activity $(\mu \mathrm{mol} / \mathrm{mg} / \mathrm{min})$} \\
\hline & \multicolumn{1}{|c}{$\mathrm{Mg}^{2+}$-ATPase } & $\mathrm{Na}^{+}, \mathrm{K}^{+}-$ATPase \\
\hline Control & $2.10 \pm 0.06 \quad(6)$ & $0.50 \pm 0.06 \quad(5)$ \\
PLC, 30 min & $1.63 \pm 0.15^{*} \quad(3)$ & $0.42 \pm 0.08 \quad(3)$ \\
PLC, 60 min & $0.92 \pm 0.08^{* *}(6)$ & $0.29 \pm 0.03^{*} \quad(5)$ \\
\hline \multicolumn{2}{|l}{$: \mathrm{P}<0.01,{ }^{* *}: \mathrm{P}<0.001$}
\end{tabular}

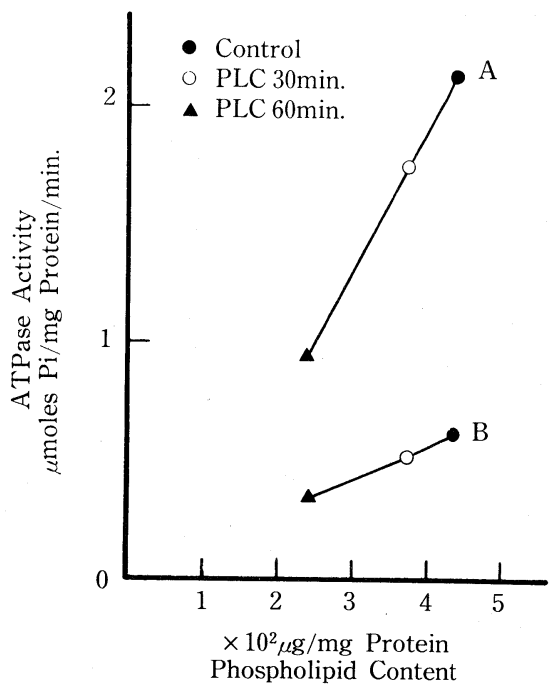

Fig 1. Relationship between ATPase activity and total phospholipid content in microsomal fractions isolated from guinea pig stomach smooth muscle treated with phospholipase C. A, $\mathrm{Mg}^{2+}-\mathrm{ATPase} ; \mathrm{B}, \mathrm{Na}^{+}, \mathrm{K}^{+}$ -ATPase. Data are expressed as mean value from 3 to 6 separate experiments. 
Table 2. Calcium uptake in the absence and the presence of ATP by microsomal fractions isolated from PLC treated and untreated stomach smooth muscle. The number of experiments are shown in the parentheses. Data are expressed as Mean \pm S.E.

\begin{tabular}{|c|c|c|}
\hline & \multicolumn{2}{|c|}{ Calcium uptake $(\mu \mathrm{mol} / \mathrm{g} / 10 \mathrm{~min})$} \\
\hline & No ATP added & $5 \mathrm{mM}$ ATP added \\
\hline Control & $1.7 \pm 0.2 \quad(6)$ & $13.5 \pm 3.0 \quad(6)$ \\
\hline PLC, $30 \mathrm{~min}$ & $1.5 \pm 0.1$ & $10.1 \pm 2.7$ \\
\hline PLC, $60 \mathrm{~min}$ & $1.3 \pm 0.3 \quad(6)$ & $7.1 \pm 1.4^{*}(6)$ \\
\hline
\end{tabular}

*: $\mathrm{P}<0.05$

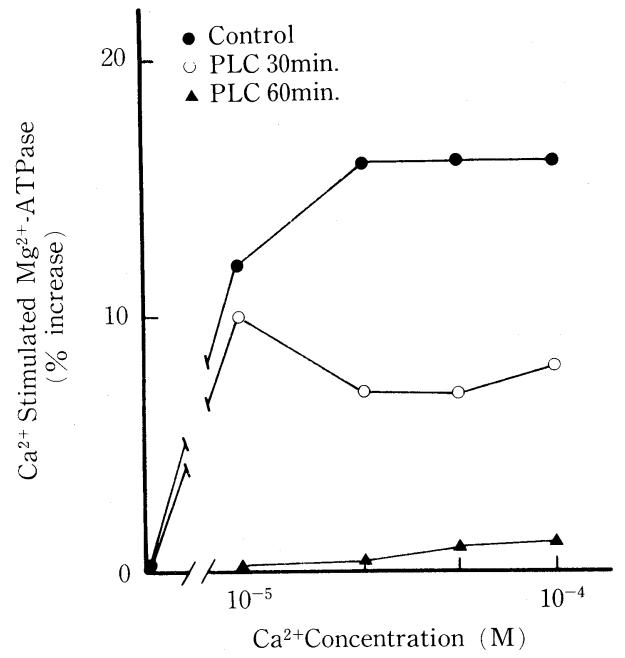

Fig 2. Calcium concentration dependence of $\mathrm{Mg}^{2+}$ -ATPase activity in microsomal fractions isolated from PLC treated stomach smooth muscle. Data are expressed as mean values from 4 to 5 separate experirents.

fractions was decreased by PLC treatment. However, this depressant effect was statistically significant only in the presence of ATP after 60 min treatment with PLC.

Effect of phospholipids on $\mathrm{Ca}^{2+}, \mathrm{Mg}^{2+}$-ATPase.

It has been reported that PLC hydrolyzes sphinogomyeline, phosphatidylcholine (PC) and phosphatidylethanolamine (PE) (Rosenberg \& Condrea, 1968). The latter two phospholipids were the major components observed in membrane phospholipids of guinea pig stomach smooth muscle in the pyloric region (Sakai, 1980). To test the hypothesis that chemical modification of these phospholipids is related to microsome ATPase activity, the effects of exogenously added $\mathrm{PC}$ and $\mathrm{PE}$ on $\mathrm{Ca}^{2+}, \mathrm{Mg}^{2+}-\mathrm{ATPase}$ was investigated. Figure $3 \mathrm{~A}$ shows that $\mathrm{PC}$ was able to effectively restore the ATPase activity of microsomal fractions which has been treated with PLC for $30 \mathrm{~min}$, but had only small effect on fractions treated for $60 \mathrm{~min}$. PE, on the other hand, did not significantly affect the ATPase activity of microsomal fractions isolated from treated muscle, but slightly inhibited the ATPase activity of the control tissue at concentrations higher than $37 \mu \mathrm{g} / \mathrm{ml}$ (Figure 3B). This effect of PE has also been reported by others (Martonosi et al., 1968; Goldman \& Albers, 1973).

\section{Discussion}

Both ATPase activity and phospholipid content decreased with increased time of PLC treatment. There was positive, linear correlation between ATPase activity and phospholipid content (Fig. 1). This could indicate that ATPase activity depends on phospholipid which is available, either directly or as a secondary result of PLC treatment. PC was able to restore $\mathrm{Ca}^{2+}, \mathrm{Mg}^{2+}$-ATPase activity of microsome fractions to near the control level after $30 \mathrm{~min}$ of tissue exposure to PLC (Fig. 3A). PE was not able to restore the ATPase activity of microsome fractions but there appeared to be a tendency to prevent activity reduction at higher 


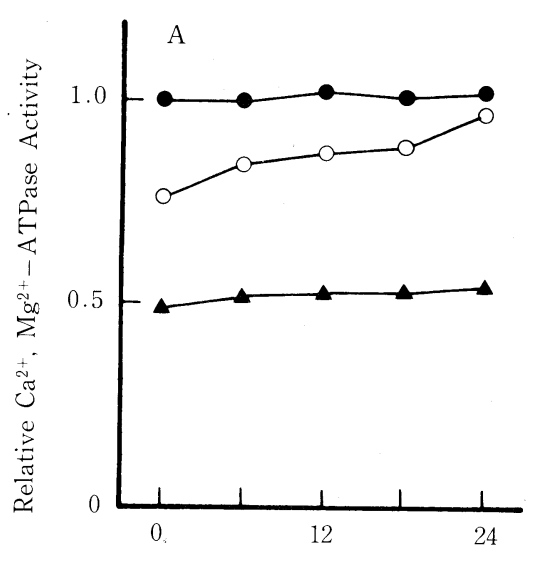

Phosphatidylcholine

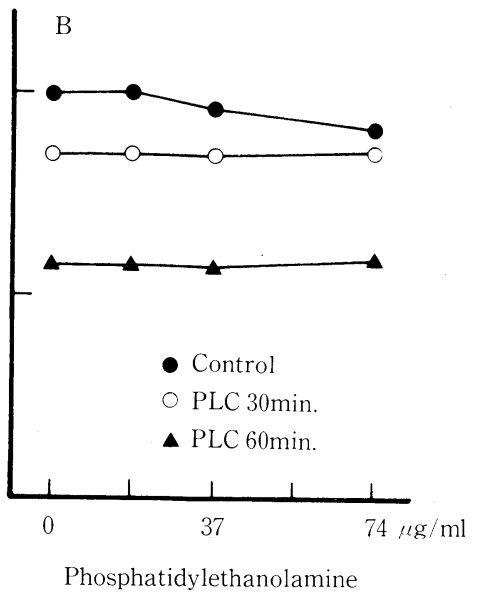

Phosphatidylethanolamine

Fig 3. Effects of phospholipids on $\mathrm{Ca}^{2+}, \mathrm{Mg}^{2+}$-ATPase activity in microsomal fractions isolated from PLC treated stomach smooth muscle. A, phosphotidylcholine added; $\mathrm{B}$, phosphotidylethanolamine added. The reaction mixture contained $0.1 \mathrm{mM} \mathrm{CaCl}_{2}, 5 \mathrm{mM} \mathrm{MgCl}_{2}, 100 \mathrm{mM}$ $\mathrm{KCl}$ and $40 \mathrm{mM}$ imidazole at $\mathrm{pH}$ 7.0. Phospholipid suspension was facilițated by supersonic treatment.

PE concentrations (Fig. 3B). This suggests that at least one PLC effect on membrane phospholipid is destructive. It also suggests that these phospholipids play a major role in ATPase activity. In skeletal and cardiac muscle microsomes, the $\mathrm{Ca}^{2+}, \mathrm{Mg}^{2+}$-ATPase has been demonstrated to be associated with $\mathrm{Ca}^{2+}$ transport system (Hasselbach, 1964). Wuytack and Casteels (1980) have recently shown that $\mathrm{Ca}^{2+}, \mathrm{Mg}^{2+}-\mathrm{ATPase}$ activity is also present in microsomal fraction isolated from vascular smooth muscle and may be related to the active $\mathrm{Ca}^{2+}$ transport system. The present work also demonstrates $\mathrm{Ca}^{2+}, \mathrm{Mg}^{2+}-\mathrm{ATPase}$ activity in stomach smooth muscle microsomes (Fig. 2). Prior treatment of tissue with PLC for $30 \mathrm{~min}$ significantly reduced microsomal $\mathrm{Ca}^{2+}, \mathrm{Mg}^{2+}-\mathrm{ATPase}$ activity and 60 min PLC treatment almost completely inhibited all ATPase activity. This suggests that phospholipids which serve as substrates for PLC are also essential for catalytic activity of $\mathrm{Ca}^{2+}, \mathrm{Mg}^{2+}-\mathrm{ATPase}$. Although PLC treatment inhibited both $\mathrm{Ca}^{2+}, \mathrm{Mg}^{2+}$-ATPase and ATP supported $\mathrm{Ca}^{2+}$ uptake of isolated microsomal fractions, a significant amount of $\mathrm{Ca}^{2+}$ uptake was resistant to PLC treatment even after $60 \mathrm{~min}$ preincubation. It is possible, however, that the residual ATP supported $\mathrm{Ca}^{2+}$ uptake seen after 60 min PLC treatment might have been due to ATP dependent binding which was substantially higher than $\mathrm{Ca}^{2+}$ binding in the absence of ATP (Kwan et al., 1981), since binding of $\mathrm{Ca}^{2+}$ by microsomal fractions was slightly but not significantly affected by PLC treatment (Table 2 ).

The decreased $\mathrm{Na}^{+}, \mathrm{K}^{+}$-ATPase activity may be related to our previous observation that PLC treatment of stomach smooth muscle caused membrane depolarization and inhibition of slow potential generation (Sakai, 1980). The decrease in $\mathrm{Ca}^{2+}, \mathrm{Mg}^{2+}-\mathrm{ATPase}$ activity and ATP supported $\mathrm{Ca}^{2+}$ uptake after PLC treatment also suggests that disturabance of $\mathrm{Ca}^{2+}$ movement in the smooth muscle cell may also be involved.

Although a heterogenous microsomal fraction was used in this study, the biochemical 
changes induced by PLC treatment is likely to be associated with plasma membrane because (a) PLC was applied exogenously to intact smooth muscle and subsequently removed proior to homogenization, (b) $\mathrm{Na}^{+}, \mathrm{K}^{+}$-ATPase and basal $\mathrm{Mg}^{2+}$-ATPase have been shown to be associated with smooth muscle plasma membrane (Hurwitz et al., 1973 ; Kwan \& Ramlal, 1982) and (c) most smooth muscles have sparse content of endoplasmic reticulum (Devine et al., 1972) and the distribution of ATP supported $\mathrm{Ca}^{2+}$ uptake parallels that of plasma membrane markers in isolated subcellular membrane fractions from various types of smooth muscles (Janis et al., 1977 ; Grover et al., 1980; Kwan et al., 1981) including stomach smooth muscles (Sakai et al., 1981 ; Kawn et al., 1982). Our present study shows that PLC is a useful tool for study of the functional role of membrane phospholipids in membrane associated enzymes and ion transport systems and the results are consistent with our previous report that PLC treatment causes smooth muscle cell membrane damage leading to inhibition of smooth muscle activity.

\section{Acknowledgement}

The authors would like to thank Dr. C.Y. Kwan for helpful discussion in the preparation of this manuscript.

\section{References}

Albuquerque, E.X. \& Thesleff, S. (1967). Influence of phospholipase C on some electrical properties of the skeletal muscle membrane. J. Physiol. (Lond.) $190: 123-137$.

Bray, G.A. (1960). A simple efficient liquid scintillator for counting aqueous solutions in a liquid scintillation counter. Anal. Biochem. 1: 279-285.

Carsten, M.E. \& Miller, J.D. (1977). Effects of prostaglandins and oxytocin on Ca-release from a uterine microsomal fraction. J. Biol. Chem. 252: 1576-1581.

Chen, P.S., Toribara, T.Y. \& Warner, H. (1965). Microdetermination of phosphorus. Anal. Chem. 28: 1756-1758.

Daniel, E.E., Crankshaw, D.J. \& Kwan, C.Y. (1979). In Kalsner, S. (editor) : Trends in autonomic pharmacology. Vol. 2. p. 443-484. Urban and Schwarzenberg Inc., Baltimore.

Devine, C.E., Somlyo, A.V. \& Somlyo, A.P. (1972). Sarcoplasmic reticulum and excitation -contraction coupling in mammalian smooth muscles. J. Cell Biol. 52: 690-718.

Fiske, C.H. \& Subbarow Y. (1925). The colorimetric determination of phosphorus. J. Biol. Chem. $66: 375-400$.

Goldman, S.S. \& Albers, R.W. (1973). Sodium-Potassium-activated adenosine triphosphatase. The role of phospholipids. J. Biol. Chem. 248: 867-874.

Grover, A.K. et al. (1980). Characteristics of calcium transport and binding by rat myomeetrium plasma membrane subfractions. Amer. J. Physiol. 239: C66-C74.

Hasselbach, W (1964). Relaxing factor and the relaxation of muscle. Progr. Biophys. Chem. 14: 169 -222 .

Hurwitz, L. et al. (1973). Location of calcium pump activity in smooth muscle. Science. 179: 384 -386 .

Janis, R.A., Crankshaw, D.J. \& Daniel, E.E. (1977). Control of intracellular $\mathrm{Ca}^{2+}$ activity in rat myometrium. Amer. J. Physiol. 232 : C50-C58.

Kwan, C.Y., Lee, R.M.K.W. \& Daniel, E.E. (1981). Isolation of plasma membranes from mesenteric veins: A comparison of their physical and biochemical properties with arterial membranes. Blood Vessels. 18: 171-186.

Kwan, C.Y. \& Ramlal, T. (1982). On the inhibition of smooth muscle membrane ATPase by sodium 
azide. Biochem. Int. $4: 439-449$.

Kwan, C.Y. et al. (1982). Isolation and characterization of plasma membrane fraction from gastric fundus smooth muscle of the rat. Mole. Physiol. 2: 107-120.

Martonosi, A., Donley, J. \& Halpin, R.A. (1968). The role of phospholipids in the adenosine triphosphatase activity and $\mathrm{Ca}^{2+}$ transport. J. Biol. Chem. 243: 61-70.

Lowry, O.H. et al. (1951). Protein measurement with the Folin Phenol reagent. J. Biol. Chem. 193 : 265-275.

Rosenberg, P. \& Condrea, E. (1968). Maintenance of axonal conduction and membrane permeability in presence of extensive phospholipid splitting. Biochem. Pharmacol. 17 : 2033-2044.

Sakai, Y. (1980). Effects of phospholipase C on electrical and mechanical activity of guinea pig stomach muscle. Jpn. J. Physiol. $30: 243-256$.

Sakai, Y. et al. (1981). Isolation and characterization of subcellular membranes from canine stomach smooth muscle. Can. J. Physiol. Pharmacol. 59 : 1260-1267.

Sulakha, S.J., Leung, N.L. \& Sulakha, P.V. (1976). Properties of particulate, membrane-associated and soluble guanylate cyclase from cardiac muscle, skeletal muscle, cerebral cortex and liver. Biochem. J. 157 : 713-719.

Tobias, J.M. (1958). Experimentally altered structure related to function in the lobster axon with an extrapolation to molecular mechanisms in excitation. J. Cell. Comp. Physion. 52: 89-126.

Wuytack, F. et al (1978). The calcium accumulation in a microsomal fraction from porcine coronary artery smooth muscle. Biochim. Biophys. Acta. 540 : 253-269.

Wuytack, F. and Casteels, R. (1980). Demonstration of a $\left(\mathrm{Ca}^{2+}+\mathrm{Mg}^{2+}\right)$-ATPase activity probably related to $\mathrm{Ca}^{2+}$ transport in the microsomal fraction of procine coronary artery smooth muscle. Biochim. Biophys. Acta. 595 : 257-263. 